УДК 821.163.41.09 Дединац М. https://doi.org/10.18485/godisnjak.2017.12.17

Тијана М. Копривица*

Универзитет у Београду

Филолошки факултет, докторанд
Оригинални научни рад

Примљен: 6. 10. 2017.

Прихваћен: 23. 10. 2017.

\title{
ТРАНСПОНОВАњЕ СТВАРНОСТИ У ДЕЛУ МИЛАНА ДЕДИНЦА
}

Разматрајући положај појединачних Дединчевих дела (Јавне птице, Једног човека на прозору и Песама из дневника заробљеника број 60211) унутар његовог целокупног опуса и надреалистичке поетике, доводећи их у везу са аутопоетичким ставовима израженим у Предговору Од немила до недрага, као и са пропратним текстовима из истог издања, намера овог рада биће да испита поступак транспоновања стварности у поезију овог аутора. Анализом наведених дела настојаће се да се покаже песников однос према стварности у оквирима уметничког текста, етапе промене тог односа и његов хронолошки развој. Будући да се транспоновање стварности одвија кроз призму лирског ја, пажња ће посебно бити усмерена на фигуру и положај лирског субјекта.

Кључне речи: стварност, транспоновање, надреализам, лирски субјект.

\section{1. Импликације}

Када 1957. године у Нолитовом издању Милан Дединац објави књигу која представља избор из личног стваралашва, пред публиком и критиком ће се наћи дело по много чему необично. Настојећи да начини репрезентативан избор свог рада, песник, који у овом случају преузима улогу приређивача, пажљиво компонује збирку и у хронолошком следу, у седам целина, слаже грађу насталу између 1926. и 1956. године. Дединац своју

*tijana.kopriva@gmail.com 
тридесетогодишњу песничку заоставштину опрема обимним дводелним Предговором, који задобија место објашњења околности у којима се рађа ново и јединствено дело, али који истовремено постаје и аутопоетички коментар о сопственом песничком развоју.

Унутар новонастале збирке свака целина је обележена редним бројем и датирана годином или периодом у коме настаје или када је објављена, и свакој претходи уводна реч која има функцију аналогну оној коју Предговор има у односу на читаву збирку. За разумевање смисла књиге, али и саме поетике Милана Дединца, у обзир се морају узети и паратекстуални елементи (попут мотоа Предговора) који наговештавају однос песника према свом делу. Мемоарски карактер дела, који ће у овом истраживању бити од великог значаја, наговештен је већ употребом цитата преузетог из Мемоара проте Матије Ненадовића. Да такав поступак на самом почетку збирке није нимало случајан, сведоче и многобројне особине, попут често присутног тона својственог литератури књижевно-научног типа који подразумева успостављање дистанце према минулим догађајима и временима, хронолошко излагање, као и слику времена уз мноштво објашњења и портрете личности (Живковић 2001: 448).

Осим прекорачења граница у жанровском погледу, предметом анализа многих књижевних проучавалаца, инкорпорирањем цртежа (графика), али и фотографија, дело превазилази окове линеарног текста и постаје интермедијална творевина. ${ }^{1}$ Овакво проширивање оквира жанра не укида композиционо јединство збирке, али собом повлачи многе поетичке недоумице чије се имликације појављују у тексту. Будући да се у текстовима који претходе свакој поетској целини садржаној у књизи Од немила до недрага налази мноштво указивања на стварност, алузије или упућивања на конкретне догађаје који су мотивисали настанак Дединчевих песма, поема и путописа, поставља се питање на који начин преплитање песничког гласа са гласом дистанцираног приређивача утиче на обликовање и разумевање финалног књижевног дела. Имајући у виду надреалистичко поимање односа уметности и стварности, односно

\footnotetext{
${ }^{1}$ Употреба различитих медија и инкорпорирање наведених елемената у сам текст једно је од основних авангардистичких поступака, које се препознаје и у поетици Милана Дединца. Техником колажирања која је присутна у Дединчевом делу подробно се бави рад Јелене Милинковић „Колаж есеја, поезије и сећања; Од немила до недрага Милана Дединца” (2009).

У Предговору Од немила до недрага песник/приређивач коментаришући технику колажа кубиста, дадаиста и надреалиста, посебно за смисао колажа у надреалистичким делима каже: „За дадаисте и надреалисте (Пикабија, Арп, Ернст, Швитер, итд...) колажи нису могли, сасвим природно, да теже било каквом пластичном циљу; напротив, они су били једна нова магија која је настојала да дискредитује Уметност и њена племенита средства, придајући притом велику улогу случају, као и најубогијим материјалима, па чак и отпацима" (Дединац 1957: 19).
} 
супротстављање реализму и подражавању, те одбацивање позитивизма, што води ирационалистичкој поетици (Новаковић 2002: 96-97), јасно је да ће у овој књизи категорија стварности бити изузетно сложена. Стварност ће бити изражена у различитим видовима, па ће се препознавати: конкретни догађаји - оно што се у историјском следу узима за стварно и поуздано; песнички доживљај конкретних догађаја - одабрани догађаји са осе историје које песник проживљава и разуме на себи својствен начин; транспонована стварност - лирски израз који настаје преламањем догађаја кроз песничку свест. Прецизније речено, имајући у виду важност коју песник/приређивач придаје својој књижевној прошлости и догађајима у њој, намеће се интересовање за механизме уметничког транспоновања стварности и њено појављивање у тексту, као и за испитивање начина обликовања лирског гласа у различитим условима, са чим је у вези и цитат Пола Елијара употребљен као још један од мотоа Предговора: „Не треба видети стварност онаквом какав сам ја".2

Анализом (анти)поеме Јавна птица, поеме Један човек на прозору и збирке Песме из дневника заробљеника број 60211, покушаћемо да представимо однос између реалног (стварног за историју и песника) и његовог одраза у литератури, својеврсног облика те стварности транспоноване у оквире лирског.

\section{2. Јавна птица - измицање смисла}

Убијам ноћи за птицом без крила у лов за птицом. Убити је нећу!

У тренутку када надреалистички покрет са средиштем у Паризу шири свој утицај по читавој Европи, постављајући пред уметност, али и пред стварност, нове захтеве, и када се напоредо са њим, мада пре званичног оформљавања надреалистичког покрета, и у тадашњој Југославији организују групе истомишљеника са водећим надреалистичким (париским) кругом, појављује се 1926. Дединчева невелика, али општеприхваћена

${ }^{2}$ У српској књижевности XX века још од 1920. године, тачније од Суматре и Објашњеља Суматре Милоша Црњанског, присутна је потреба да се објасни настанак једног конкретног уметничког дела. С друге стране, треба имати у виду да, као што примећује Јелена Милинковић, већ 1954. године Душан Матић издаје своју Багдалу, а да две године након објављивања Дединчеве књиге Од немила до недрага у Просветином издању излази књига Милоша Црњанског Итака и коментари. Поетичке везе (поред посведочених личних веза између ова три песника) које би могле постојати између ових великих подухвата којима песници објашњавају генезу свог стваралаштва свакако јесу тема за размишљање и засебан рад. 
(анти)поема; Јавна птица постаје узорни пример који испуњава надералистичке поетичке тежње и очекивања, бар што се тиче незваничног београдског круга. ${ }^{3}$ Њеној успешној рецепцији доприносе текстови Душана Матића, Марка Ристића и Растка Петровића, и сви они једногласно прихватају Јавну птииу као врхунски поетски израз који превазилази сва дотадашња песникова опробавања у лирици. ${ }^{4}$

Наслов изражен необичном синтагмом, односно именицом уз коју је употребљен њој несвојствен придев, најављује доминантан мотивски комплекс који ће бити изражен у антипоеми, како је сам песник у недостатку бољег одређења назива (Ристић 1965: 36), чиме се оцртава и његов амбивалентан однос према наслеђу и традиционалним песничким облицима. Такође, с обзиром на тему и мотив, у извесној мери се потврђује и за ово Дединчево дело оно што Радован Вучковић примећује у вези са Дединчевом, Ристићевом и Вучовом поезијом насталом до 1925. године: „наслов наговештава идеју, а централни мотив је без двосмислености усаглашен за поетском замисли" (Вучковић 2011: 323). С друге стране, наслов представља и контрадикторност, будући да придев ,јавна” не одговара личној драми коју песник настоји да дочара.

Потрага за мистичном птицом представљена је низом сцена, песничких слика, које су међусобно повезане сродним, али ипак доста слободним асоцијативним спрегама и које представљају главни произдвод надреалистичког стварања (Новаковић 2002: 139). Наизменичним и брзим смењивањем поетских и прозних секвенци успоставља се фрагментарна структура дела (у делу има тачно шеснаест фрагмената), чему доприноси и то што су прозни делови поеме изразито поетизовани. Оваква „разломљеност" додатно се истиче несталношћу лирског гласа, који се кроз текст варира употребом првог и трећег глаголског лица, чиме песник производи утисак вишегласја.

Самом тексту Јавне птице, песниковом/приређивачевом вољом, придружени су текстови под насловом Белешке и дневник о Јавној птици, који постају елемент користан за разумевање дела. У настојању да објасне пут настајања Јавне птице, својим насловом Белешке пред реципијентску свест постављају очекивање есејистичко-дневничког дискурса засићеног

\footnotetext{
3 За више о односима париске и београдске надреалистичке групе видети: Новаковић 2002: 7-11.

${ }^{4}$ Навешћемо овде критике, пре панегирике Јавне птице и афирмације надреалистичког става: Марко Ристић, „Објава поезије” у: Марко Ристић, Уочи надреализма, Нолит, Београд, 1985. стр. 136-141; Душан Матић, „Поводом књиге Милана Дединца” у: Душан Матић, Битка око зида, Матица српска/Српска књижевна задруга, Нови Сад/Београд, 1971. стр. 50-52; Растко Петровић, „Милан Дединац” у: Есеји и чланци, Нолит, Београд, 1974, стр. 171-176.
} 
чињеницама. Овакво ишчекивање није у потпуности изневерено, будући да се поједини делови описани у Белешкама врло лако препознају као мотиви и поступци у поетском тексту (на пример, мотив смеха, мотив путовања/потраге, начин дескрипције простора). Међутим, када је у питању део назван Дневник о Јавној птищи ситуација се у извесном смислу мења. Омогућавајући увид у два навода из Дневника, приметно је да се они својом датираношћу уистину подударају са захтевима које дневник као жанр подразумева, док сама суштина, смисао и стил дневничког записа као да има врло мало од тих карактеристика. Чак и само летимичним читањем приметно је да се и у Дневнику песник служи поступком којим је ткана сама Јавна птиия - напоредом употребом поетских и прозних делова; но проблематичност природе записа не лежи само у томе што су у њега укључени стихови, што би био легитиман поступак било ког писца дневника, већ и у томе што се сам текст у великој мери приближава лирском дискурсу. Не остављајући места фактографији у Дневнику о Јавној птици, бар у оноликој мери у којој би она била препозната, односно измештајући трагове фактографског у Белешке, Дединац заправо даје непосредан и непрепричан, управо песнички развој свог дела.

Положај који лирски субјекат Јавне птище заузима унутар књижевног дела умногоме зависи од представе света која се образује у свести, а с обзиром на надреалистичку поетику и у подсвести лирског субјекта, те се тако субјекатска позиција посредно дефинише (Радоњић 2013: 277-284). Од великог значаја јесте и већ поменута несталност лирског гласа. Наиме, употребом трећег лица песник успева да предочи својства лирске позорнице, лирски субјекат се именује као Зорило, чиме се Дединац аутореферише на своје раније песме из циклуса Зорило и Ноћило. Укључивањем првог лица као начина изражавања, осим што се добија јасан увид у осећања, размишљања и асоцијативни ток лирског субјекта, отвара се могућност за стварање дијалогичне ситуације. Много пута ће апострофирање бити пропраћено императивном реченицом, али и питањем које остаје без одговора, чиме се отвара могућност за сумњу у постојање онога коме се лирски глас обраћа. Преплитањем два наизглед различита гласа постиже се умножавање перспектива из којих се свет Јавне птице успоставља.

Описивање лирске позорнице почиње већ у првом запису у стиховима „пре него Сунце сване” (Дединац 1965: 115) назначавањем одсуства Сунца и светлости, па се заједно са исказом ${ }^{5}$ „Зора се љуља” (Дединац 1965: 133) који се налази на самом крају поеме, постављају границе времена у којем

${ }^{5}$ Бојана Стојановић Пантовић у својој студији „Јавна птица Милана Дединца и дискурс песме у прози" истиче да је основни израз песме у прози или прозаиде (како се још може 
се одиграва потрага за птицом, а које се односе на време ноћи. Трајање потраге одређено је синтагмом „три сеобе птица”, чиме се реферише на три године између 1923. и 1926. и на песников исказ о почетку стварања дела. ${ }^{6}$ Сличан случај је и са одређењем простора који окружује лирског субјекта. Присутне су шуме, грање, вода, односно море, трава, цвеће, а спомиње се и Град, па се смењивањем и претакањем простора природе и урбане градске средине наглашава непрестано кретање лирског субјекта у потрази за својом птицом, чиме се лирска ситуација додатно динамизује. У поимању простора прави се опозиција између познатог и непознатог, где се кућа изражава као уточиште и место сигурности насупрот свем другом простору, што ће бити чест топос у Дединчевој поезији. Овакво представљање простора и времена, посебно доведених у везу са сном, проузрокује да њихове границе у извесним тренуцима постају нестабилне, због чега се стиче утисак да се лирски субјекат налази на прелазу између сна и јаве, у ониричном амбијенту, што одговара надреалистичкој афирмацији сна и несвесног (Надо 1980: 22; Новаковић 2002: 43-44). Такође, овакво обликовање две компоненте отвара могућност за уочавање појединих елемената који се проналазе у делима бајковите структуре. Непрестано кретање напред са јасним циљем чијем се испуњењу стреми даје овом делу изразиту динамичку црту, док измицање жељеног када се нађе надомак лирског гласа управо подстиче трагање. Томе у прилог иде и последњи исказ у поеми „ПО ДЕТЕЛИНИ КОРАЧАМ...” (Дединац 1965:133), који, осим што је одређен својом финалном позицијом, постаје истакнут и у типографском смислу, чијом се поруком инсистира на непрекинутости трагања и по окончању читања поеме. На основу ових елемената, а имајући и у виду природу поеме као жанра, јасно је да суптилна наративизација ипак опстаје упркос надреалистичким тежњама за укидањем наратива и изразито снажним лирским сликама којима се Дединац служи (Надо 1980: 77; Новаковић 2002: 145).

Сам мотив птице, осим у наслову, не јавља се одмах са почетка, већ испрва алтернира са другим појмовима. Стихови „Блесни!/ Сини кроз чуда/ кроз просторе, кроз снове/ Прасни у град" указују на муњу, звезду или неку другу небеску појаву, да би се са Зориловим проналаском птића увео сам главни мотив, који касније повремено бива замењен мотивом звезде: „Звездо, звездо у небу ти, а ја те љубим...”, а услед љубавне конотације

посматрати Јавна птица) исказ, а не стих. У овом случају, ми ћемо се послужити тим изразом имајући у виду првенствено прозне делове поема Јавна птица и Један човек на прозору.

${ }^{6}$, „Ја сам још у лето 1923 почео да је гоним, да гоним и прогањам ту своју махниту птицу, птицу љубави” (Дединац 1965: 137). 
и са фигуром девојке незнанке: „О, не дај ме девојко незнана тиха испод мене". Променљив карактер онога за чим се трага проширује спектар могућих значења мотива птице, из чега проистиче метафоричност мотива, али и то да поема постаје својеврсна алегорија. Мотив птице у тесној је вези са мотивом песме, који најчешће фигурира као потврда тајанственог присуства у одсуству жељене и тражене птице, са чим је у вези и мотив сенке која искрсава, као и мотив смеха који се повремено чује („Смеје се незнани човек”; „Тако сам провео ноћи од једног смеха до ду́ге” (Дединац 1965: 121, 128)) и који проналази своје објашњење у додатим белешкама („Другови ми се смеју. И ја се са̂м смејао. Смејао се самоме себи, заиста...” (Дединац 1965: 139)).

Из оваквих поставки слике света произилази, експлицитно и имплицитно, да су основна осећања лирског субјекта бол, усамљеност, неспокојство, чежња за љубављу, али и потреба да се истраје и пронађе птица, што би довело до смирења. Оваква алегоријска, наизглед недоречена, али у својој суштини вишезначна слика призива макар три могућа значења. Прво, на нивоу света саме песме где се потрага за птицом предочава као потрага за смислом, што даље води апстрактнијем преливању значења алегорије у нешто поједностављенију слику животног пута. Друго значење могло би бити поетичко, у којем се мотив птице и потраге предочавају као доживљај чина стварања уметничког дела што, напослетку, води ка трећем и најуопштенијем значењу које се тиче схватања самог феномена надреализма и песникове улоге у њему.

\section{3. Један човек на прозору - деконструкција тела}

Ја сам разапет паук на прозору

Нешто више од десет година након појаве Јавне птице, Дединац се оглашава новом поемом Један човек на прозору. Замишљена као спој два различита дискурса који се међусобно допуњују, поема прати надреалистички импулс склоности ка испробавању и експериментисању. Двострукост дискурса поларизује текст дела на поетски и журналистички, али и условљава њихов међусобни однос према принципу „загонетка : одгонетка". Фактографски фрагменти новинских текстова од 14. априла 1937. године издвојени поднасловом POST SCRIPTUM транспарентно пружају увид у догађаје који постају лирска позадина рефлексивно-медитативног доживљаја. У својој белешци Поводом поеме Један човек на прозору Душан Матић каже: „Подухватајући се овог превођења поједино- 
сти једне безличне природне појаве на језик најличнијих осећања песник је хтео да буру спољног света изрази својом буром" (Матић 1966: 143), те се зато поставља питање управо о начину на који се превазилази јаз створен супротстављањем догађаја и доживљаја.

Сам поетски текст испресецан одредницама попут: ЧЕТВРТ ЧАCA КАСНИЈЕ, ПОСЛЕ ПОЛА ЧАСА БЕСМИСЛЕНОГ СТОЈАЬА, МАЛО ДОЦНИЈЕ, ПОСЛЕ КАШЉА, заједно са проговарањем у првом лицу у интимистичком тону ствара атмосферу дневничког записа. С друге стране, поигравањем са истим овим смерницама и указивањем на минималне временске размаке између забелешки ствара се утисак симултаности, непосредности и непрекинутости стања у коме запис настаје, као да се садржај ума аутоматски преводи у речи, што јасно указује на надреалистичке тежње ка испуњавању диктата мисли. ${ }^{7}$ Да прекинутост јединственог душевног стања ипак постоји потврђују реченице као, на пример, следећа: „Још сам разапет на прозору" (Дединац 1965: 158). Једна мисаона нит прекинута је рефлексном реакцијом (кашљем), што је праћено напуштањем положаја стеченог у тренуцима искорака у несвесно и сусретом са својом објективном позицијом. На исти начин може се разумети и последња реченица поеме, када се прецизним датирањем завршава и заокружује песничка творевина и доживљај опеван у њој (Дединац 1965: 160). Поред формалне подељености на коју се наилази у тексту присутна је и графичка подвојеност за којом песник посеже. Наиме, и у овом његовом делу стихови се смењују са паусима написаним у прози. Међутим, разлике у стилском и тематском изразу у ова два типа текста нема, већ се та разлика у случају поеме Један човек на прозору запажа само на визуелном плану. Мотиви се надовезују један на други и преносе из једног типа текста на други, што ће бити случај и са мисаоним целинама и са ритмом поеме, као и са другим песничким средствима својственим изразу у стиху, што указује на поетизацију прозе. Мото преузет од Александра Блока „Ветри у лету на целом божијем свету” (по узору на поему Дванаесторииа (Блок 1964: 111)) даје први траг за разумевање дела, усмерава пажњу на конкретну појаву и истиче кључни мотив ветра који ће на различите начине бити вариран кроз читаву поему.

\footnotetext{
${ }^{7}$ Према Манифесту надреализма који је сачинио Андре Бретон, у преводу Марка Ристића стоји дефиниција: „Надреализам: м. Чист психички аутоматизам којим се покушава изражавање, било усмено, било писмено, или ма којим другим путем, стварност делања мисли. Диктат мисли у одсуству сваке контроле од стране разума, ван сваке естетичке или моралне намере” (Ристић 1985: 104).
} 
Већ сам наслов, довољно индикативан, у центар пажње поставља човечију прилику уоквирену и истакнуту окном. Непрецизно одређен идентитет особе поменуте у наслову ствара контраст у односу на прво лице једнине којим поема почиње и у коме ће бити испевана до краја. Утисак спољашње перспективе (а не перспективе лирског субјекта) уклања се одмах на почетку, те упућује на јасну усмереност лирског гласа од споља ка унутра. Ужаснутост као наглашено осећање постаје полазиште за разматрање позиције лирског субјекта који ће се успоставити у овом Дединчевом делу. Поимање самог себе као тела међу другим телима усковитланог у магли, као разједињено тело у које треба ући, у сагласју je са осећањем ужаснутости и проистиче из њега, подједнако колико проистиче и из немогућности да му се отргне. Овакве играрије са различитим звучним, гласовним ефектима, тумарање тела у етру, помногоме подсећају на Снежну маску и песму Гласови већ евоцираног Блока. Чин стајања на прозору окарактерисан је као бесмислен и служи као алтернатива трагању за уточиштем и истовремено се супротставља динамици дешавањâ која песник опева. Физички положај, такође, директно утиче на видик лирског субјекта, а самим тим на његову слику света, а затим и на одређење сопствене позиције у њему. Прозор традиционално протумачен као место дотицања два света, као граница, задржава нешто од таквих својих особина и, осим што постаје осматрачница, повллашћено место у односу на остатак света и збивања у њему, указује на егзистенцијално проблематичан положај онога ко се ту налази. Амбивалентност смештања лирског субјекта у простору појачава се истовременим посматрањем догађаја, али са физичком дистанцом и одсуствовањем из њих.

Осим формалних одлика и паратекстуалних елемената који значајно утичу на одређење и схватање положаја лирског субјекта у овом Дединчевом делу, важно место заузима питање телесности. Већ на самом почетку натуралистички описи доносе доживљај истрошеног, празног и шупљег тела које претрајава у времену. Поступним рашчлањивањем тела на делове који му припадају, њиховим каталошким набрајањем, песник описује доживљај живота лирског субјекта служећи се метонимијом. Појединачни делови тела (попут руку, плућа, срца, стопала) постају персонификовани носиоци догађаја својствених њиховој првобитној биолошко-друштвеној функцији. Тако ће се, на пример, руке изнурити и задихати рукујући се, милујући, дајући, машући, додирујући, једући и пијући, стопала истрошити ходањем и подношењем притиска, а утроба истрошити услед вршења разних унутрашњих процеса тела. Основна животна рефлексна акција дисања, аналогијом изниклом на асоцијативним везама између дисајних 
органа и кретања ваздуха у организму, и у природи постаће тесно повезана са ветром, што ће даље водити њиховом изједначавању: знају плућа куда је све овај ветар прошао који сад тако махнито у юих с налетом улази и кида/ па на уста излази/ и даље, све даље иде ветар/ Оде, у поља оде/ - Цепа плакату са зида -/ Ветар, ах ветар, ветар што стално ветар одлази (Дединац 1965: 153).

Ова аналогија води наредној, за један степен уопштенијој аналогији која претпоставља изједначавање света са лирским субјектом, тачније, оно што се дешава споља преноси се у буквалном смислу у унутрашњост човека на прозору. На сличној асоцијативној логици почива и осећање разапетости лирског субјекта, које је такође у вези са ветром и које је више пута у тексту наглашено. На пример, слика простртог веша који ветар шиба (Дединац 1965: 152) претходи исказивању осећања лирког субјекта да су кости и кожа разапети, из чега се јасно уочава путања мисаоног тока. Како су и узроци таквог осећања из перспективе лирског субјекта побројани, занимљиво је уочити да се између њих и лирског субјекта, односно његовог тела, успоставља нит која подразумева повезаност готово пантеистичке природе: „од Месечевих либращија [...] од космичких помрачења [...] од траве испод ноћи веће од прашуме, и од њених лудих и грозних, од юених ужасно равномерних гравитаиија" (Дединац 1965: 149-150).

Сама појава ветра у поетском тексту демистификује се увидом у приложене новинске чланке који сведоче о непогодама, али и наредним исказом у коме се ветар јавља у свом персонификованом облику: „Овај ветар иза прозора јутрос је испод Аде Хује на обалу Дунава сишао, црвен и знојав да се добро напије воде" (Дединац 1965: 155). Осим приписивањем телесних особина као у наведеном примеру, персонификација се врши и придавањем умних способности, па ће тако ветар имати моћ свезнања. Ветар је, такође, окарактерисан као „ветар што стално ветар одлази” (Дединац 1965: 153), чиме се указује на његову несталност и тежњу за лутањем, што имплицира посредну сличност са Дединчевом мистичном, Јавном птицом. Настојање да се именовањем ветрова (маестрал, пасати, југо, развигор, широко, ћорава анђелија (Дединац 1965: 153-154)), тј. набрајањем његових врста и истицањем за сваку врсту специфичних особина, појам ветра одреди, доводи до уопштавања појаве и њеног проширивања и на друге пределе. Ветар задобија и своју временску одредницу „ветар између векова”, што заједно са географским одредницама (са Океана, на обали Шпреве, на Пагу, у Прагу, на Сени (Дединац 1965: 154)) води успостављању тоталитета света кроз време и простор.

Тема градацијског распарчавања лирског субјека започета описима трошног тела, а настављена употребом мотива ветра и даха усложњава се 
увођењем других особа (недовољно индивидуализованих, али довољно присутних да би биле утицајне) које потпомажу приказан процес. Туђем даху придају се разарајућа својства ветра, туђи дах се меша и замењује са сопственим, да би се затим метафорика проширила и у супротном смеру, и на друге временске непогоде, попут поплаве („Tуђе су поплаве y мени. Ја их толике, пуне жуте воде, надошле, ја их одиста никада нисам видео..." (Дединац 1965: 156)), или свакодневну појаву, као што је смена дана и ноћи (,Мој мрак се надима, напиње се; он сада бије и рије, он трује и стење, и спава у другим људима" (Дединац 1957: 160)). Замена места опозицијама своје и туђе, односно продирањем туђег у своје, доводи до потребе за преиспитивањем идентитета, а затим и до разарања граница лирског субјекта и његове потпуне деконструкције.

Представа разорености кулминира усредсређивањем на демонизовану слику Сунца, која се још на самом почетку поеме јавља у назнакама као црно-сива светлост која изазива бол (мотив који ће Дединац пратити и у потоњој лирици, нпр. у песми Ноћ дужа од снова (Дединац 1965: 331-333)). Зракови светлости металног сјаја које Сунце исијава премрежавају небески свод, те он постаје као кавез, док се разапета пауколика човекова фигура преувеличава и преовладава читавим простором. Утисак ухваћености који доминира на крају поеме приређивач издања Од немила до недрага доводи у везу са својим есејем У трагағу за изгубљеним детиғством, чије делове и прилаже уз поему. Иако тај есеј настаје 1939, две године након Једног човека на прозору, песник увиђа блискост између главног осећања које се јавља у ова два текста (Дединац 1957: 172). Политичка и духовна клима историјског тренутка описана у есеју, а која подразумева неспокојство, страх и недостатак слободе, одговара егзистенцијалном положају лирског субјекта поеме. Навођење изостављеног пасуса есеја у коме се сведочи о неповољном положају уметника у друштву само је још једна потврда присуства репресивног режима, нетолерантног и непријатељски расположеног према онима чији су ставови другачији. Релација која се при томе изводи самој поеми даје још једну могућност тумачења, дотада ненаметљиву, изражену само ретким и далеким алузијама, попут наглашеног статуса руку (симбола радника) и рудара: „О руке што су се у буни први пут обнажиле” (Дединац 1965: 151), „О, зар је дах тога рудара толико у мене урастао/ а ја сам с тим човеком јуче, тек само кратко говорио!" (Дединац 1965: 155). Тон социјалне критике и потреба да се уметничким ангажманом утиче на стварност и живот приближава Дединца надреалистичком схватању револуције и социјалне правде (Надо 1980: 101). Схватање живота „Од вриска свог рођења” (Дединац 1965: 156) 
као апокалиптичко-пророчке визије непрестаног кружења, усковитланог ломљења, као подношење „притиска тих сталних над овом стиснутом главом" (Дединац 1965: 157), поред субјективних и тренутних разлога, какви су олуја и положај лирског субјекта у њој, сада се допуњава друштвеним положајем који песник заузима, чиме се границе између лирског субјекта и песника, ако не бришу, онда значајно смањују.

\section{4. Песме из дневника заробљеника број 60211 - заједничко искуство}

При покушају да се говори о транспоновању стварности и положају који лирски субјекат услед тога заузима у Песмама из дневника заробљени$\kappa a$ број 60211, немогуће је то чинити не узевши у обзир друштвено-историјски контекст у којем ова збирка настаје. Записи из овог дела настали су у периоду између 1941. и 1943. године, за време Дединчевог заточења у немачким нацистичким логорима у Загану и Герлицу, да би 1947. били објављени као песничка збирка и сведочанство. Дневник је вођен у тајности, мисли су записиване на ситним рукописом малим комадима хартије и чинио се сваки напор да се догађаји сачувају од заборава (Дединац 1957: 198). У том смислу, већ и паратекстуални елементи попут наслова, мота, поднаслова сведоче о искуству које је тематизовано у песничкој збирци. Наслов у себи садржи жанровску одредницу која упућује на интимни карактер записа и присуство личне црте, док речи које одређују припадност дневника изражавају прихватање и помиреност онога који бележи са дехуманизацијом и деперсонализацијом људских бића, свођењем на један број. Фигура и осећање човека који чами узета за мото најављује егзистенцијалну атмосферу описану у збирци и став о сопственом бићу онога који бележи.

Разматрајући проговарање у првом лицу, стид првог лища, аутор наглашава да не постоји други начин осим тог и да то $j a$ које је присутно у себе сажима свако појединачно $j a$ које са њим дели заједничко искуство боравка у заробљеничком логору, при чему му контрастира своје некадашње $а$ које је „постојало само да би пламсало оним чиме се разликује од других" (Дединац 1965: 171). Свеобухватност исповедног ја, његова колективност, у супротности је са конвенцијама дневничке литературе, а донекле и са надреалистичким тежњама да се представљањем искуства уз помоћ дневничке прозе дође до аутентичног ја (Стојановић Пантовић 
2012: 113-114). С друге стране, колективно ја одговара особинама феномена логорашке литературе или, како је Јовица Аћин назива, логорологије (1984: 6-7). Потреба да један проговори у име свих у заробљеничким логорима разних врста показује се као двосмерна, дакле, постоји и у свести оног који проговара, али и оних који очекују да о њима буде проговорено. Срамно искуство транспоновано уметничким средствима, узимање од других да би им се вратило, надилази функцију посведочавања о друштвеним чињеницама и постаје поетски израз естетске вредности. Наслов првог од три композициона дела у збирци Заробљенички број 60211 пева (подвукла Т. К.) заједно са речју Песма из наслова дела сугерише значај саме радње певања, усамљеног вољног чина под присмотром стражара. Певање и производ певања постају еквиваленти живота и јединог могућег начина опстанка у нељудским условима (Аћин 1984: 9-10).

Жанровска укрштања у самом делу, односно лирски записи уметнути међу дневничке записе, условљавају постојање два гласа који проговарају. ${ }^{8}$ Први би био онај који бележи и чува свакодневне догађаје и призоре из заробљеничког живота, описује осећања и страдања - исповедно $а$ исказано лиризованом дневничком прозом. Медијум који преноси слику света коме припада неретко се налази у позицији посматрача, па се из тог разлога у записима дневничке природе уочава учесталост употребе глагола који подразумевају чулна опажања различите врсте: гледам, видим, посматрам, осматрам, слушам, чујем. Такође, прозне пасаже одликује свест о настанку песме/песама, те ће зато бити присутни искази попут наредних:

Певају моји другови, [...], и ја сам са њима, [...], па шапућем речи што једна за другом ничу у мени, и напрежем сву мисао да их задржи, како бих могао, [...], да их у бараци, кришом, запишем.

Па гледам у ту руку крваву, и гледам у мутна небеса, а у мени негде на дну, можда крај срца, чујем песму;

Такао ме је горко и одјекнуо у срцу тај очај и ритам тих речи, па је наставио, сву ноћ, да се ломи и нејасно прелама у мени, и да се претвара у речи...;

${ }^{8}$ Разлика између ова два доминантна ауторска гласа, прозног и поетског, изражена је и на типографском нивоу. Тако се прозни елементи текста штампају обичним слогом, док су поетски делови обележени курзивом. Оваква графичка дистинкција на први поглед делује обичном, но се она може посматрати, уз нешто произвољног тумачења, и као врло ефектна и успела. Тако, на пример, делови текста писани обичним слогом и визуелно (као и садржајем) одговарају утиску одмереног виђења стварности, фактографског, тежњу ка објективном маркирању догађаја и промишљања. С друге стране, курзив својим изгледом асоцира на рукопис, на белешку аутоматизовану и са циљем да на што непосреднији начин пренесе ток: мисли, осећања, рефлексије; на такав начин твори се и визуелни, али и суштински лирски део текста. 
После, од сељака из Босне, записујем у бараци синоћну песму. И уносим у њу - без потребе - неке ситне, незнатне промене, тек да бих је што тешње привезао за себе (Дединац 1965: 175, 181, 189, 194).

Указивање на конкретне ситуације из којих постају одређене песме артикулишу поетичку самосвест песника поводом сопствене улоге у тренутку када стваралачка ситуација није најповољнија, али и поводом 'мисије' коју преузима на себе, али и која обезбеђује memento логорашког искуства. Наведени пасуси сведоче о начинима на које се транспоновање догађаја и ситуација у овом књижевном делу врши, а који, осим превазилажења нељудских услова ради бележења, подразумевају дубоко промишљање о опаженом. Из душевног стања подстакнутог догађајима исповедно $j a$, које прошушта кроз себе сваки моменат и осећање сваког од другова, настаје други глас, доживљајно $а$, које себе изражава у стиховима. Кришом забележене импресије преображавају се у рефлексивне описе догађаја и раположења, услед чега се два субјекатска гласа међусобно укрштају и заједнички стварају целовиту слику света и времена из којег ауторско ја сведочи. Тако Милан Дединац поводом читања Баладе човека који је уснио мреже у дворани Правног факултета каже: „Балада човека који је уснио мреже могла би, чини ми се, унеколико да послужи као један од примера како се код песника, бар мога типа, врши транспозиција доживљаја из конкретне друштвене стварности у лирски израз" (Дединац 1967: 89), што би се могло прихватити и поводом читаве збирке којој Балада припада.

Жанровску поливалентност издања Песама из дневника заробљеника број 60211 из 1964. године, осим коментара и напомена, посебно наглашавају и увећавају бакрописи Мила Милуновића, инспирисани управо овом збирком. Црно-беле илустрације које прате поједине записе у визуелном погледу приближавају песничку збирку реципијентима и доприносе њеној мултимедијалности. У издању Од немила до недрага из 1957. међу Песме из дневника заробљеника број 60211 нису уврштени никакви ликовни елементи (за разлику од Јавне птице и Једног човека на прозору које у овом издању имају и своју графичку допуну).

Упечатљиве слике заробљеничких колона које не напуштају своју кружну путању унутар логорских жичаних ограда, као што је:

Кружимо по песку, док понорно море изнад наших глава, или сунчано и мирно, или олујно и тмурно, ветром витлано, кишом шибано, или Сунцем миловано, запљускује нас сад топлим мирисима шуме што бол у чежњу буде, сад хладним ветровима који, кроз логорску жицу и кроз ребра наша, танко наричу (Дединац 1965: 177). 
јесу међу најдоминантнијима и показују да временски услови и у овом Дединчевом делу преокупирају песника и подстичу његову имагинацију. За разлику од Једног човека на прозору, појава ветра и мотив ветра ће бити драстично негативно конотирани. Непрестано падање кише о коме се сведочи условиће инвертовану представу библијског мотива Нојеве барке, односно потопљену барку/бараку која насукана не налази никакво спасење (Дединац 1965: 178). ${ }^{9}$ У прилог томе служи и изостанак дуге као симбола мира и нове наде, чиме се јасно имплицира положај у коме се субјекат налази. Искуство олује представљено је анимализованим појавама ветра и мећаве који урлају, завијају и реже. Простор, осим хоризонталног ограничења - логорских жица и гвоздених мрежа, задобија и вертикално ограничење у виду ниског, вечито тмурног неба, које се надноси над њиховим главама и повија их: „Од облака ниских не могу главу да одигнем, од кише очи да отворим" (Дединац 1965: 177). На овај начин простор омеђен са свих страна бива отуђен од стварног света и постаје не-простор. Осећање ухваћености, метафорички схваћено у поеми Један човек на прозору, сада је изазвано дословним заробљеништвом, о чему најбоље сведочи Балада човека који је уснио мреже, у којој се антиципаторски описује стање духа, немир и неспокојство који ће се обистинити у годинама рата. Представљена изопштеност омогућава изокретање перспективе, па се небо над затвореничким главама поима као морско пространство (Зашто ме узносиш), а простор робовања се премешта на морско дно и изједначава се са њим (На морском дну).

Сунчева светлост је ретко присутна, па зато помрчина у којој се лирски субјекат налази има за последицу неразликовање дана и ноћи. Свакодневна понављања воде истоветности и изједначавању свих дана, одакле се ствара утисак да су им животи заробљени у једином дану у коме је време престало да протиче (Светиљке, Опасна игра, Робље игра коло разлупаних фењера, Замишљени сужањ гледа прозирне руке и слуша песму у себи). У свом споју не-простор и не-време отварају митске просторе и времена, па се појединачна жртва, поред колективне хоризонтале тј. међусобног повезивања логорских другова, повезује и колективном вертикалом кроз стање ванвременског поретка са свим прошлим и будућим страдалницима. Лирски глас и у овом случају трпи промене преузимајући визуру туђег ока,

${ }^{9}$ У комуникацији са овом песничком сликом налази се и бакропис назван Лира, који се налази и на насловној страни целовитог издања ове збирке из 1964. године. На слици је представљена лира, симбол песништва, која по свом обличју подсећа на митску дрвену барку. Затамњене површине које подсећају на преплетене жице и мреже и које прекривају лиру јасно упућују на симболочки значај овог ликовног додатка. 
безименог брата из давнина (Дединац 1965: 179) са којом се поистовећује и са којом се стапа, образујући тако архетипску фигуру жртве.

Нељудским условима којима су заробљеници изложени, поред излагања временским непогодама, на којима су заробљеници приморани да раде или их само подносе као вид кажњавања, придодати су и глад и изгладњивање. Персонификована глад, како је представљена у песми $A$ онда је банула глад, подстиче извитоперење људских особина. Људске прилике опеване су као кост и јад, просврдлана тела, да би се изједначиле са самом фигуром глади црне косе и белог лица, великих уста и провидних ушију. Насилничку борбу за храну, грабеж, прати стварање анимализоване слике онога што је био човек (Белешка од 20 јула 1941), па се стари - човечији идентитет успоставља једино у сну. Низу записа, лирских и дневничких, који сведоче о изгладњивању и тескоби која из истог произилази придружен је бакропис под насловом Гавран, који својом уверљивошћу активира традиционалну представу о злослутности и омражености појаве ове птице и који одговара опису заробљеника као птица грабљивица (Дединац 1964: 33). Питање идентитета и отуђености од самог себе покреће се и у лирском запису људи, распети на жици постављају себи свакидашња питања: који припада Шлеској рапсодији од јутра до сутра, другом делу Песама из Дневника заробљеника број 60211. Запитаност о сопству изаражава се сумњом у могућност положаја у коме се људи, распети на жици налазе и освешћивањем новостеченог идентитета: „,- Јесам ли то ја, ја иза ове жице?/ [...] - Јесам ли ја тај сужағ што га стража са куле чува?/ [...] - Да ли је то мој глас што се на број одзива, ветрови куд га односите?" (Дединац 1964: 61).

Време ноћи удружено са поменутим простором сна, темељне категорије важне за Дединца, али и за све остале надреалисте, конституише се као простор могућности и простор паралелне егзистенције. У сну се допире до завичаја који постоји као место живота и љубави, па се уочава јасна опозиција између овде и тамо, односно не-простора и простора. ${ }^{10}$ Ступањем у простор сна наставља се напуштени живот, комуницира се са вољеним бићима, па лирски записи ове тематике имају нешто интимнији тон (Зашто ме узносиш, 25 јул 1941, После буђења) и приближавају се поетичким очекивањима постављеним пред жанр дневника. Мисао о животу другог бића на бољем месту постаје слабашан извор утехе за

${ }^{10}$ Детаљније о опозицији завичај : логор и средствима која се та опозиција успоставља пише Александар Јовановић у својој студији „Завичајна мелодија у логорској осами - о Песмама из дневника заробљеника број 60211 Милана Дединца" (2014: 318). 
заточеног, о чему сведочи песма 25 jул 1941, која настаје након пријема првог писма од куће.

На овај начин, кроз анализу стихова из Дневника заробљеника број 60211 , јасно се уочава да је слика стварности транспонована у лирске оквире непосредно, те да се при њеном уобличавању израз чини условљеним од стране контекста. То и не чуди будући да је реч о опеваном логорском искуству чије размере надилазе поимање људског и песничког, и пред чијом стварношћу свака метафора изгледа ништавно и ублажено. Императив овог лирског састава није у преобликовању стварности у поетско рухо, већ се он налази на граници између документовања датог тренутка и борбе са песничким импулсом; на њој, стварности која је и одвише натуралистички присутна, Дединац успева да сачини један од најзначајнијих и најтрауматичнијих поетско-документарних текстова српске књижевности.

\section{5. Стварност : поезија}

Распон од две деценије у опусу Милана Дединца изнедрио је три његова најпознатија дела, која ће, уз друге, бити укључена у коначну збирку Од немила до недрага. Поетичке промене које се за то време одигравају на ширем плану, као што је радикално окретање социјалном аспекту у уметности или тежња ка ширењу њених утицаја ван артистичких граница, на стварност, одражавају се и на Дединчево стваралаштво.

Најхерметичније од свих Дединчевих дела, узор-поема Јавна птица, собом испољава типично надреалистичке карактеристике: гранични положај између сна и јаве, онирична визија подређена диктату подсвести, онеобичавање исказа употребом (а)логичних асоцијативних веза, неочекиваних епитета, генитивних метафора, мешањем лирских гласова и др. Објашњења која би требала да допринесу бољем разумевању поеме написана су у поеми блиском стилском регистру, те је тако не расветљавају у потпуности, већ се њено значење усложњава, продубљује и шири ван граница самог текста. Стварност постаје окидач за стварање песничких слика које образују алегорију о птици, по много чему митској слици. Наведена својства поеме у највећој мери одређују положај лирског субјекта, па ће се сходно томе у њему препознати надреалистичко поимање човекове егзистенције. Овакво гледиште подразумева настојање да се превазиђе јаз створен између себе и света и да се достизање хармоније омогући преласком у ирационално (Новаковић 2002: 17), што би у овом случају значило трагањем за неухватљивом птицом. Различите перспективе про- 
говарања омогућавају стварање целовите слике света у коме се лирски субјекат нашао. Ипак, подвојеност лирског гласа не доводи до потпуне дезинтеграције лирског субјекта, већ његова целовитост ипак опстаје и одржава се јединственим духовним подухватом са којим је суочен, упркос његовом неизвесном исходу.

Поетичка промена која се уочава са Једним човеком на прозору могла би се описати као окретање друштвеној, заједничкој стварности, а не ономе што је од значаја искључиво за појединца. Разматрајући формалне одлике, лако се запажа да песничка имагинација извире из конкретних догађаја, због чега механизми транспоновања стварности постају знатно уочљивији и лакши за представљање. У том смислу, приложена документаристичка грађа се јавља смишљено, као додатак и помоћ при разумевању надреалистички конципиране поеме Један човек на прозору, док се са временским одредницама, које би могле постати гарант веродостојности, тек поиграва. Дединац остаје доследан свом песничком изразу наново се служећи надреализму својственим поступцима онеобичавања, нагомилавања, снажном асоцијативношћу и у стилском погледу метонимијом, метафором, поређењима и паралелизмима. Међутим, за разлику од Јавне птице, оно што је изражено у поеми Један човек на прозору није оспољавање унутрашњег, већ преусмерен процес који резултира поунутарњењем спољашњег. Из оваквог приступања грађи произилази утисак о потпуној дестабилизацији света и са тим повезана потпуна дезинтеграција/деконструкција субјекта.

Приређен заробљенички Дневник истовремено је веродостојан документ и поетски запис о проживљеном. Значај и значење дела превасходно су одређени контекстом настанка који је немогуће занемарити, чиме се ово дело издваја међу осталима и задобија повлашћено место у Дединчевом опусу $^{11}$. Имајући у виду Адорнов, иако касније поречен, став о смислу уметности и писања поезије након холокауста, преиспитивање статуса уметности насталој у епицентру злочина и патњи наставља се и поводом овог дела. Да је у питању нешто налик насушној потреби, стање у коме се живот изједначава са поезијом, где би потирање једног условило нестанак другог, доказује песников положај посредован лирским субјектом. Полазиште стварања које условљено спољашњим елементима не завршава се сублимирањем појава у свести или подсвести лирског субјекта. Супрот-

\footnotetext{
${ }^{11}$ Јелена Милинковић такође разматра разлоге због којих је збирка Песме из дневника заробљеника број 60211 повлашћена и поред наведеног питања контектуализације истиче и чињеницу да је ово једина Дединчева збирка која је имала два издања, 1947. и 1964. године (Милинковић 2014: 333).
} 
но томе, доживљајем насталим из специфичних околности и догађаја, а који је посредован гласом лирског субјекта, обухватају се и други који присуствују истим околностима. Ни у овом делу изражајна средства се не мењају битно. Однос према сопственом $j a$ и позиционирање $j a$ у односу са другима у Дневнику најсродније је ставу који аутор о свом ја изражава у Предговору издања Од немила до недрага: прихватање нецеловитости у једном тренутку на једном месту и током времена.

Евидентна потреба да се говори о околностима настанка сопствених дела, са мање или веће дистанце, а затим да се она уланчавају у већу целину, доводи до питања о хијерархији између стварности и уметничког израза. Оваква потреба пред тумача опуса Милана Дединца ставља раскошну грађу, где се уз песнички материјал у анализу укључује и аутопоетичко становиште самог аутора. Сагледавајући транспоновања стварности (онакве каква она јесте била, те онакве какву ју је песник видео и артикулисао у свом делу) тумач мора направити известан укрштај спољашњег и унутрашњег приступа, јер се управо на размеђи стварног и доживљеног одвија и Дединчева највећа поетичка инспирација. Из анализираних песничких творевина намеће се следећи закључак: свест о трансформацијама сопственог $а$ под утицајем времена и различитих околности које из кретања времена произилазе биће пропорционална уделу стварности у уметничком делу.

\section{ЛИТЕРАТУРА}

Аћин 1986: J. Aćin, Književna logorologija u: J. Aćin (ur.) Delo, god. XXXII, sv. 4-5, Beograd, 1-17.

Блок 1964: A. Blok, Pesme, Beograd: Rad.

Вучковић 2011: Р. Вучковић, Поезија српске авангарде, Београд: Службени гласник.

Дединац 1957: M. Dedinac, Od nemila do nedraga, Beograd: Nolit.

Дединац 1964: М. Дединац, Песме из дневника заробљеника број 60211, Београд: Просвета.

Дединац 1965: М. Дединац, Позив на путовање, Београд: Просвета.

Живковић 2001: D. Živković, Rečnik književnih termina, Banja Luka: Romanov.

Јовановић 2014: А. Јовановић, Завичајна мелодија у логорској осами - о Песмама из дневника заробљеника број 60211 Милана Дединца, у: С. Јаћимовић, С. Шеатовић Димитријевић (ур.), Поезија и поетика Милана Дединща, Београд: Институт за књижевност и уметност, 313-330. 
Матић 1966: Д. Матић, Поводом поеме Један човек на прозору, у: С. Велмар-Јанковић (прир.), Къижевност између два рата, књ.2, Београд: Нолит.

Матић 1971: Д. Матић, Поводом књиге Милана Дединца, у: Д. Матић, Битка око зида, Нови Сад/Београд: Матица српска/Српска књижевна задруга.

Милинковић 2014: Ј. Милинковић, Искуство поезије, поезија искуства: логорологија Милана Дединца, у: С. Јаћимовић, С. Шеатовић Димитријевић (ур.), Поезија и поетика Милана Дединца, Београд: Институт за књижевност и уметност, 331-352.

Надо 1980: M. Nado, Istorija nadrealizma, Beograd: BIGZ.

Новаковић 2002: J. Novaković, Tipologija nadrealizma, Beograd: Narodna knjiga/Alfa.

Петровић 1974: Р. Петровић, Милан Дединац у: Р. Петровић, Eсејu и чланци, Београд: Нолит.

Радоњић 2013: Г. Радоњић, Позиција лирског субјекта у поезији Новице Тадића у: С. Владушић (ур.), Летопис Матице српске, књ. 492, св. 3, септембар 2013. Нови Сад: Матица српска, 277-284.

Ристић 1965: М. Ристић, О поезији Милана Дединца и о нашој младости, предговор у: М. Дединац, Позив на путовање, Београд: Просвета.

Ристић 1985: M. Ristić, Objava poezije, u: M. Ristić, Uoči nadrealizma, Beograd: Nolit.

Ристић 1985: M.Ristić, Nadrealizam u: M. Ristić, Uoči nadrealizma, Beograd: Nolit.

Стојановић Пантовић 2012: B. Stojanović Pantović, Pesma u prozi ili prozaida, Beograd: Službeni glasnik.

Стојановић Пантовић 2014. Б. Стојановић Пантовић, Јавна птиия Милана Дединца и дискурс песме у прози, у: С. Јаћимовић, С. Шеатовић Димитријевић (ур.) Поезија и поетика Милана Дединца, Београд: Институт за књижевност и уметност, 251-264.

\section{Публикаичја доступна on-line:}

Milinković, Jelena. Kolaž eseja, poezije i sećanja; Od nemila do nedraga Milana Dedinca. Agon, časopis za poeziju, broj 03, maj-jun, 2009. 4.8.2017. 
Tijana M. Koprivica

\title{
TRANSPOSING OF REALITY IN MILAN DEDINAC'S OPUS
}

\begin{abstract}
Summary
Considering the place of Dedinac's individual works (Javna ptica, Jedan čovek na prozoru and Pesme iz dnevnika zarobljenika broj 60211) within his opus and poetics of surrealism, relating them with autopoetical attitudes expressed in Predgovor (Prolegomena) of Od nemila do nedraga and also with accompanying texts from the same publication, this work will intetnt to examine the process of transposing reality into poetry of this author. Analyzing the mentioned author's works, this paper will try to highlight poet's treatment of reality in the textual frame, stages of changing the way of treatment and its chronological development. Since transposing reality is unfolding trough the prism of the lyric subject, focus will be, especially, on figure and position of the lyric subject.
\end{abstract}

Key words: reality, transposing, surrealism, lyric subject. 